\title{
Event Volunteer Satisfaction Research on the Relationship between the Service Performances-Based on Analysis of the Mediation Effect of Psychological Contract
}

\author{
Shuhua Xia, Mingliang Li \\ Henan Normal University, College of Physical Education, Xinxiang 453007, Henan, China
}

\begin{abstract}
In this paper, 287 volunteers from the 11th Traditional Games of Ethnic Minorities were investigated, the relationship among job satisfaction, service performance and psychological contract of volunteers in sports events was studied by using correlation analysis and hierarchical regression analysis, to examine the mediating effect of psychological contract on satisfaction and service performance of event volunteers. The results show that (1) there is a significant correlation between satisfaction, service performance and psychological contract, and the positive correlation Coefficient between satisfaction and service performance is 0.448 , the correlation coefficient between satisfaction and psychological contract was $r=0.342$, and the positive correlation coefficient between psychological contract and service performance was $r=0.827$, both of which had significant level on P \& Lt; 0.01 (2) psychological contract and job satisfaction have positive influence on service performance. The higher the degree of psychological contract and job satisfaction, the better the service performance. (3) the degree of satisfaction with the work of the match volunteers can effectively improve the achievement of the psychological contract, and the achievement of the psychological contract is conducive to the improvement of the service performance of the match volunteers, psychological contract has a significant mediating effect between satisfaction and service performance. The direct effect (0.1599) and the mediating effect (0.227) of this model account for $41 \%$ and $59 \%$ of the total effect (0.3869) respectively. Therefore, a sound communication channel should be established between the organizers and the volunteers, a scientific and reasonable incentive mechanism should be established, the management level of the organizers of the Games should be raised, and the degree of work satisfaction and psychological contract of the volunteers should be enhanced, improve the service performance, enhance the influence of the competition.
\end{abstract}

Keywords: Event volunteers; Job Satisfaction; service performance; psychological contract; mediating effect

\section{Introduction}

Modern organization theory holds that the process in which job satisfaction affects job performance and job performance is regulated and controlled by psychological contract between employees and organizations ${ }^{[1]}$, which is based on mutual trust between organizations and employees. For organizations and leaders, a successful psychological contract is the equal psychological expectation, emotional identity and responsibility weight between organizations and employees, which extends to employees' loyalty to organizations and spontaneous follow-up to leaders, while a failed psychological contract leads to the deterioration of the relationship between employees, organizations and leaders, which is manifested in the low efficiency of employees' work and the loss of trust and loss of control in the relationship between superiors and subordinates ${ }^{[2]}$. The psychological contract conveys an immaterial psychological expectation except for a written contract between the organization and the members, while voluntary service is a kind of public welfare behavior that zealously serves others or the society in a personal way without seeking material returns. It will help sport event organizations to adopt effective governance strategies and incentives, and promote the improvement of job satisfaction and psychological contract formation among event volunteers to enhance voluntary service performance to study the relationship between job satisfaction, service performance and psychological contract of event volunteers, and to discuss the mediating effect of psychological contract on the satisfaction and service performance of event volunteers by introducing the

ISSN: 0010-8189

(C) CONVERTER 2021

www.converter-magazine.info 
theory of psychological contract into field of volunteer management of sports events.

\section{Research Hypotheses}

\subsection{Job satisfaction and service performance of event volunteers}

In recent years, a large number of research results have emerged around the relationship between job satisfaction and performance, and the argument that job satisfaction has a positive impact on performance has been increasingly accepted, but get different conclusions from different research fields and angles. Bai Hongbin $(2013)^{[3]}$, Sheng Danhua (2014) ${ }^{[4]}$, Zhang Hong $(2014)^{[5]}$ Wang Xiaojie $(2016)^{[6]}$ Wen Yi $(2016)^{[7]}$ believed that employee job satisfaction has a significant positive impact on job performance. Zhang Jian, Shen Piao ${ }^{[8]}$ et al. thought that job satisfaction will affect not only employees' job performance, but also their job behavior and organizational performance. Hui Tiaoyan ${ }^{[9]}$ believed in 2006 that external job satisfaction leads to task performance, task performance leads to internal job satisfaction, internal and external job satisfaction together lead to positive changes in related performance, and internal job satisfaction has a greater impact on related performance than external job satisfaction. However, some scholars have different views. Zhang Xing (2011) ${ }^{[10]}$ found that no matter whether factors such as teacher ability and school are excluded, the two are not related. Ma Weikun $(2016)^{[11]}$ studied the relationship among perceived organization support, psychological capital, job satisfaction and job performance of new generation knowledge workers, and found that job satisfaction has no significant effect on job performance. The impact of job satisfaction on performance is relatively complex, although in practice they are also affected by other variables such as organizational commitment and work engagement, there is a correlation between job satisfaction and job performance.

Thus, the following research hypothesis is made: H1: Job satisfaction of event volunteers has a significant positive correlation with service performance.

\subsection{Research on the internal relationship between psychological contract and job satisfaction}

Xiong Yongqing and Qu Yadan ${ }^{[12]}$ found that psychological contract is highly positively related to employee satisfaction, and the fulfillment of psychological contract can positively predict job satisfaction. Wu Zhonghua $(2014)^{[13]}$, Tan Ming et al. (2014) ${ }^{[14]}$, Bai Shenghao (2014) ${ }^{[15]}$, Jiang Yanjun $(2019)^{[16]}$ et al. studied the relationship between psychological contract and satisfaction of different subjects such as third-party logistics companies, new generation female migrant workers, teachers and community workers, and found that the fulfillment of psychological contract is significantly positively correlated with satisfaction of different subjects, and the fulfillment of psychological contract has an interactive effect on job satisfaction. Jin Fang, Zhao Yiming, Wang Zhao et al. (2020) ${ }^{[17]}$ think that kindergarten contract fulfillment and teacher contract fulfillment can positively predict job satisfaction, but kindergarten contract fulfillment is more predictive. Liu Wei, He Mi'na (2013) et al. ${ }^{[1]}$ believed that psychological contract has a significant moderating effect on the relationship between job satisfaction and extra-role behavior, and when the psychological contract between employees and organizations is strong, high job satisfaction will lead to employees' organizational citizenship behavior, while when it is weak, job satisfaction will easily induce employees to implement anti-organizational behavior. Yuan Ling, Dai Bo and Zhang Leilei $(2014)^{[18]}$ argued that psychological contract violation has a significant mediating effect between psychological contract destruction and job satisfaction, and has a significant moderating effect between psychological contract destruction and psychological contract violation. Xu Yanying's $(2014)^{[19]}$ related research proves that college teachers' job satisfaction plays a mediating role between psychological contract and job burnout, and psychological contract indirectly affects job burnout through job satisfaction. Thus, the following hypothesis is made based on the above achievements:

H2: Psychological contract fulfillment can significantly and positively affect job satisfaction.

ISSN: 0010-8189

(c) CONVERTER 2021

www.converter-magazine.info 


\subsection{Research on the internal relationship among psychological contract, satisfaction and job performance}

Looking at the existing research results, the relationship among job satisfaction, psychological contract fulfillment and job involvement is explored from the perspectives of role ${ }^{[20]}$, leadership style, work characteristics ${ }^{[21]}$ and management support ${ }^{[22]}$. A large number of research results at home and abroad show that the establishment and maintenance of psychological contract is positively correlated with job performance, while the violation of psychological contract is negatively correlated with job performance. Li Dandan, Meng Bei (2017) ${ }^{[23]}$ Kou $\mathrm{Di}^{[24]}(2018)$ and Yi Zhongwu ${ }^{[25]}(2018)$ et al. studied the effects of psychological contract on job performance of different subjects such as nurses in public hospitals, employees in state-owned enterprises, and police, and found that different subjects all showed that the more satisfied the psychological contract was, the higher the employee performance would be. Compared with transactional psychological contract, relational psychological contract can lead to higher job quality and satisfaction of employees. Qiao Qiyao ${ }^{[26]}(2020)$ thought that the violation of relational psychological contract has obvious negative impact on organizational commitment and job performance, and employees are more concerned about the relational psychological contract that can establish long-term stable relationship. Li Dandan, Qi Yulong, et al. $(2015)^{[27]}$ held that employees' attitude and behavior towards the organization will be appropriately adjusted according to the fulfillment of psychological contract they perceive. Ma Ling, Wang Yu et al. (2013) ${ }^{[28]}$ found that organizational commitment plays a partial mediating role in the relationship between job satisfaction and job performance. Li Chong, Zhang Li et al. (2016) ${ }^{[29]}$ believed that satisfaction plays a completely mediating role between salary structure and scientific research performance, while job involvement plays a completely mediating role between satisfaction and performance. To sum up, the fulfillment of psychological contract can make employees have good psychological experience and higher job satisfaction, and the improvement of job satisfaction can positively predict job performance and improve service quality. By the same token, the fulfillment of psychological contract of volunteers in sports events promotes them to actively participate in volunteer service, improves their satisfaction, and produces loyalty and follow-up to volunteer service organizations, thus improving their volunteer service performance. Thus, the following hypotheses are made

H3:Psychological contract fulfillment has a significant positive impact on service performance.

H4: Psychological contract mediates job satisfaction and service performance.

\section{Research Methods}

\subsection{Subjects}

With the method of random sampling, an online questionnaire was designed to investigate the volunteers who participated in the 11th Traditional Games of Ethnic Minorities. A total of 287 valid questionnaires were collected. Among the subjects, 104 were male (36.2\%) and 183 were female (63.8\%), including 110 subjects at the junior college level and below (38.3\%), 7 subjects were freshmen (2.4\%), 95 (33.1\%) were sophomores, $68(23.7 \%)$ were juniors, $5(1.7 \%)$ were juniors, and $2(0.7 \%)$ were postgraduates or above.

\subsection{Tools}

3.2.1 Job satisfaction scale for event volunteers

Based on the Job Satisfaction Scale compiled by Macdonald and Macintyre(1997), the scale in this paper is a one-dimensional structural scale consisting of 10 items, such as "I am recognized for my excellent work", "I am happy with my work in this organization", and "I am satisfied with the assigned position". Through the analysis of the service nature of the event volunteering work, the contents of the items were revised to include the satisfaction of the event volunteers on various aspects of the event organizers, such as the satisfaction degree on recruitment and selection, the satisfaction degree on training management, the satisfaction degree on basic service guarantee, and the satisfaction degree on self-development. The Likert 5-level scale was adopted, which ranged from "very 
dissatisfied" to "very satisfied", with a score of 1-5 points. The reliability and validity of the scale were tested, and Cronbach Alpha was 0.939 and KMO value was 0.926 , indicating that the scale had good reliability and validity and could be tested.

3.2.2 Psychological contract scale for event volunteers

A psychological contract fulfillment questionnaire for event volunteers was designed. Based on the Psychological Contract Questionnaire of Millward and Hopkins(1998) and the Psychological Contract Questionnaire of Rousseau(2001) and the three-dimensional structure of the Psychological Contract Questionnaire of New Employees of $\mathrm{Li}$ Yuan (2002), the normal responsibility, interpersonal responsibility and development responsibility, the two-dimensional structure of the questionnaire was determined as realistic responsibility and development responsibility. The Cronbach Alpha value and the KMO value were 0.879 and 0.941 , respectively, indicating good reliability and validity of the scale.

3.2.3 Service performance scale for event volunteers

In this study, a scale for service performance developed by Bettencourt and Brown (1997) was used, which consisted of two parts: intra-role performance and extra-role performance. Each part was composed of five measurement questions, and was scored with 5 points ( 1 for "totally disagree" and 5 for "totally agree"). The internal consistency reliability in this study was 0.946 .

\section{Analysis on Research Results}

4.1 Correlation analysis on job satisfaction, psychological contract and service performance of event volunteers

According to the description and related analysis results (Table 1), the summary of psychological contract, satisfaction and service performance scores clearly shows that the average values of psychological contract, satisfaction and service performance are 4.765, 4.019 and 4.660. The data in Table 1 shows that the satisfaction of the investigated volunteers has a significant positive correlation with service performance $(r=0.448, p=0.01)$, indicating that the satisfaction of event volunteers has a positive effect on service performance, that is, the higher the satisfaction of event volunteers, the higher the service performance will be, and the lower the job satisfaction of event volunteers will affect the service performance of event volunteers and reduce the quality of volunteer service provided by event volunteers. The correlation coefficient between the satisfaction of the event volunteers and the psychological contract reaches a significant level $(r=0.342, \mathrm{p}<0.01)$, which indicates that the higher the satisfaction of the event volunteers is, the higher the psychological contract level is. On the contrary, when the satisfaction is lower, the psychological contract satisfaction is also lower, and there is a significant positive effect between the two. The psychological contract of event volunteers is also significantly positively correlated with service performance $(\mathrm{r}=0.827, \mathrm{p}<0.01)$, that is, the higher the degree of psychological contract of event volunteers, the higher the service performance of event volunteers. On the contrary, the low degree of psychological contract achievement of event volunteers will reduce the service quality and service performance of event volunteers.

Table 1 Descriptive statistics and correlation analysis results of psychological contract, satisfaction and service performance of event volunteers

\begin{tabular}{|c|c|c|c|c|c|}
\hline Category & $\mathbf{M}$ & SD & Psychological contract & Satisfaction & Service performance \\
\hline Psychological contract & 4.765 & 0.403 & 1 & & \\
\hline Satisfaction & 4.019 & 0.558 & $.342 * *$ & 1 & \\
\hline Service performance & 4.660 & 0.474 & $.827 * *$ & $.448 * *$ & 1 \\
\hline
\end{tabular}

4.2 Mediating effect of psychological contract between satisfaction and service performance

Process was used to test the mediation model, and Model 4 (a simple mediator model) in SPSS macro compiled by

ISSN: 0010-8189

C CONVERTER 2021

www.converter-magazine.info 
Hayes(2012) was used to test the mediating effect of psychological contract on the relationship between satisfaction and service performance while controlling gender and grade. The results (Tables 2 and 3 ) show that satisfaction had a significant predictive effect on service performance $(B=0.39, t=7.98, P<0.001)$ and the direct predictive effect of satisfaction on service performance was still significant $(B=0.16, t=5.24, P<0.001)$ after the intermediate variable was added, that satisfaction had significant positive predictive effect on psychological contract $(\mathrm{B}=0.33, \mathrm{t}=5.82, \mathrm{p}<0.0001)$, and the positive predictive effect of psychological contract on service performance was also significant $(\mathrm{B}=0.68, \mathrm{t}=22.79, \mathrm{P}<0.001)$. In addition, the upper and lower limits of bootstrap $95 \%$ confidence interval of the direct effect of satisfaction on service performance and the mediating effect of psychological contract did not contain 0 (see Table 3), which indicated that satisfaction can not only directly predict service performance, but also predict service performance through the mediating effect of psychological contract. The direct effect (0.1599) and mediating effect $(0.227)$ of the model accounted for $41 \%$ and $59 \%$ of the total effect $(0.3869)$, respectively.

Table 2 Mediating model test of psychological contract

\begin{tabular}{|c|c|c|c|c|c|c|c|}
\hline \multicolumn{2}{|c|}{ Regression equation $(\mathrm{N}=\mathbf{2 8 7})$} & \multicolumn{3}{|c|}{ Fitting index } & \multicolumn{3}{|c|}{ Coefficient significance } \\
\hline $\begin{array}{l}\text { Outcome } \\
\text { variables }\end{array}$ & $\begin{array}{c}\text { Predictive } \\
\text { variables }\end{array}$ & $\mathbf{R}$ & $\mathbf{R}^{2}$ & $\mathbf{F}$ & B & $\mathbf{t}$ & $\mathbf{P}$ \\
\hline \multirow[t]{4}{*}{$\begin{array}{c}\text { Service } \\
\text { performance }\end{array}$} & & 0.46 & 0.21 & 25.27 & & & \\
\hline & Gender & & & & -0.18 & -1.80 & 0.07 \\
\hline & $\begin{array}{l}\text { Level of } \\
\text { education }\end{array}$ & & & & -0.02 & -0.59 & 0.55 \\
\hline & Satisfaction & & & & 0.39 & 7.98 & 0.00 \\
\hline \multirow[t]{4}{*}{$\begin{array}{l}\text { Psychological } \\
\text { contract }\end{array}$} & & 0.35 & 0.12 & 12.78 & & & \\
\hline & Gender & & & & -0.03 & -0.22 & 0.82 \\
\hline & $\begin{array}{l}\text { Level of } \\
\text { education }\end{array}$ & & & & -0.03 & -0.79 & 0.43 \\
\hline & Satisfaction & & & & 0.33 & 5.82 & 0.00 \\
\hline \multirow[t]{5}{*}{$\begin{array}{c}\text { Service } \\
\text { performance }\end{array}$} & & 0.85 & 0.72 & 183.55 & & & \\
\hline & Gender & & & & -0.16 & -2.73 & 0.01 \\
\hline & $\begin{array}{l}\text { Level of } \\
\text { education }\end{array}$ & & & & 0.00 & 0.07 & 0.94 \\
\hline & Satisfaction & & & & 0.16 & 5.24 & 0.00 \\
\hline & $\begin{array}{c}\text { Psychological } \\
\text { contract }\end{array}$ & & & & 0.68 & 22.79 & 0.00 \\
\hline
\end{tabular}

Note: All the variables in the model are substituted into the regression equation after standardization, the same below.

Table 3 Table of total effect, direct effect and mediating effect

\begin{tabular}{cccccc}
\hline & Effect & $\begin{array}{c}\text { Boot } \\
\text { SE }\end{array}$ & \multicolumn{2}{c}{ BootLLCI BootULCI The value of opposite effect } \\
\hline Mediating effect of psychological contract & 0.227 & 0.0399 & 0.1506 & 0.307 & $59 \%$ \\
Direct effect & 0.1599 & 0.0351 & 0.0906 & 0.2274 & $41 \%$ \\
Total effect & 0.3869 & 0.048 & 0.293 & 0.481 & \\
\hline
\end{tabular}

Note: BootSE, BootLLCI and BootULCI refer to the standard error of indirect effect estimated by percentile Bootstrap method with deviation correction, and the lower limit and upper limit of $95 \%$ confidence interval respectively. All values were rounded to three decimal places, the same below.

\section{Discussion}

With the continuous development of China's economy and the influence of the international community, the 
large-scale sports events in our country have developed rapidly, which cannot be separated from the hard work of the event volunteers in organizing the events. Although the volunteers are selfless in nature, they also have certain psychological demands, such as being able to see their favorite athletes, improve their skills in certain aspects in the event service, or simply help others to experience the realization of the resulting sense of self-value. Psychological contract is a variety of beliefs about responsibilities and obligations formed between employees and organizations on the premise of their relationship with organizations, based on commitment and perception. It also refers to a tacit cooperation between individuals and organizations in giving and returning, which has an important influence on the attitude and behavior of organizations and individuals. Job satisfaction, job participation and organizational commitment are the basic indicators to measure employees' psychological state in the organization, and employee job satisfaction is the core of organizational psychological contract management. The purpose of psychological contract management is to enhance employees' job satisfaction, enhance their sense of belonging to the organization and promote their job performance.

In this study, aiming at the special group of event volunteers, combing the research results of the impact of satisfaction on service performance, a model with psychological contract as a mediating variable was constructed to explore the role of psychological contract between event volunteers' job satisfaction and service performance, and verify the impact of event volunteers' job satisfaction on service performance through the mediating role of psychological contract. The research results are of some theoretical and practical significance for the event organization department to improve volunteer management, improve the service quality of the events, bring good experience to the audience and athletes, and enhance the popularity and influence of the events.

\subsection{An analysis on the internal relationship between job satisfaction and psychological contract of event volunteers}

From the data analysis in 3.1, it is found that the job satisfaction of the event volunteers is significantly positively correlated with the psychological contract, and the psychological contract has significant positive predictive ability on the job satisfaction, which is consistent with the conclusions of Lai Lijuan ${ }^{[30]}$ (2016) that a good psychological contract can positively affect employees' physical and mental pleasure and job well-being, that is, when employees' psychological contract is satisfied, their job satisfaction will be correspondingly improved, their recognition of relationships in the organization will be enhanced, and their relationship performance will be automatically improved. Generally speaking, job satisfaction includes not only the material elements of psychological contracts such as salary and working conditions, but also the spiritual elements of psychological contracts such as job responsibilities, value realization and organizational culture ${ }^{[31]}$ (Lei Gang, 2020). Event volunteers, as a special group, are somewhat different from ordinary company employees, which is reflected in the fact that company employees pay attention to the supply of organizational material elements, while event volunteers have low demand for material elements, pay more attention to spiritual pursuit, and have essential differences in psychological needs. When event volunteers can fully experience the organization's supply of spiritual elements, their sense of identity and belonging to the organization will increase, which will affect their work attitude and service quality. The event organizers should reasonably satisfy the psychological demands of the event volunteers, enhance their job satisfaction, motivate their work enthusiasm and enhance their sense of belonging to the organization. All these will help fully tap the human resources potential of the event volunteers and facilitate the efficient operation of the event organization. At the same time, the event organizer can guide the event volunteers to promise service quality by increasing their job satisfaction, and then restrain the midway loss of event volunteers and other behaviors violating the organization regulations.

\subsection{The effect of psychological contract fulfillment on service performance of event volunteers}

The results of correlation analysis in 3.1 show that the psychological contract fulfillment of event volunteers is significantly related to their service performance, and the psychological contract of event volunteers has a positive predictive effect on service performance, that is, the higher the psychological contract of event volunteers, the better their service performance, whereas the lower the psychological contract achievement will reduce the service

ISSN: 0010-8189

C CONVERTER 2021

www.converter-magazine.info 
quality of event volunteers, which is consistent with the research conclusion that the improvement of psychological contract fulfillment plays an important role in promoting the service performance of employees ${ }^{\text {[32][33][34]. }}$. Satisfaction and job involvement of volunteers determine their job performance, thus affecting the organization and service level of events ${ }^{[35]}$. Psychological contract rupture is negatively correlated with employee engagement, while employee engagement is positively correlated with employee job performance. The more serious the psychological contract breach, the lower the overall performance level of employees ${ }^{[36]}$. As psychological contract contains personal psychological expectations for a well-organized working environment, safety and sense of belonging, value recognition, training and development opportunities, promotion, etc., it is helpful to apply psychological contract to event volunteers, deeply analyze their inner expectations for the organization, and help them fully understand the content and nature of their work, so as to establish a reasonable expectation and improve their service performance. Because the psychological contract is based on the prediction of the future of the organization, the deviation between reality and expectation will lead to feelings such as loss and dissatisfaction. At this time, it is necessary for the organizers of the event to communicate deeply with volunteers, to know in time which aspects of the organization deviate from the expectations of volunteers, and to understand the inner expectations of volunteers through communication and negotiation. Moreover, the organizer should investigate whether the volunteers' reasonable expectations and unfulfilled expectations are due to the volunteers themselves or the organizer after the events, and summarize these experiences through timely reflection and feedback, so as to promote the fulfillment of the psychological contract of the volunteers and the realization of the goal of effective allocation of human resources in the event organization, and further promote the improvement of the service performance of the volunteers.

\subsection{Mediating role of psychological contract in job satisfaction and service performance of event volunteers}

According to the data analysis in 3.1 and 3.2, the job satisfaction of event volunteers has a significant predictive effect on service performance, which is still significant after adding psychological contract as a mediating variable. Both job satisfaction and psychological contract fulfillment of event volunteers affect service performance of event volunteers, that is, service performance of event volunteers is affected not only by job satisfaction but also by psychological contract, and satisfaction can predict service performance of event volunteers through psychological contract as a mediation. As a mediating variable, psychological contract organically links job satisfaction and service performance of event volunteers, which is consistent with the research results of Zhong Siyuan (2016) ${ }^{[37]}$ that organizational non-material incentives for employees have a significant positive impact on psychological contract and psychological contract on job performance, in which psychological contract can play a mediating role. Liu Wei, He Mi'na, Yang Bo et al. (2013) ${ }^{[1]}$ also found that psychological contract has a significant moderating effect on the relationship between job satisfaction and extra-role behavior, and when the psychological contract between employees and organizations is strong, high job satisfaction will lead to employees' organizational citizenship behavior, while when it is weak, job satisfaction will easily induce employees to implement anti-organizational behavior. Different perceptions of psychological contract will have different influences on employees' work performance and work behavior. In terms of subject nature, although there are essential differences between event volunteers and general employees, they are still restricted by this law. In event service, the higher the job satisfaction of event volunteers, the better their psychological contract perception is, the easier it is to induce high-quality service behavior. Psychological contract plays a significant mediating role in event volunteers' job satisfaction and service performance. Therefore, it is necessary to pay attention to the investigation and analysis of the job satisfaction and psychological contract perception of event volunteers, promote the good perception of psychological contract by improving the job satisfaction of event volunteers, strive to achieve the reasonable psychological expectation of event volunteers, enhance the perception level of psychological contract, enhance the sense of organizational identity, stimulate the enthusiasm of event volunteers, optimize the service quality, improve the management level of competition organization and expand the influence of competition.

ISSN: 0010-8189

(C) CONVERTER 2021

www.converter-magazine.info 


\section{Conclusions and Suggestions}

\subsection{Conclusions}

(1) Satisfaction and service performance of event volunteers are significantly correlated with psychological contract. The correlation coefficient between event volunteers' satisfaction and service performance is $r=0.448, p$ $<0.01$, that between event volunteers' satisfaction and psychological contract is $\mathrm{r}=0.342, \mathrm{p}<0.01$, and that between psychological contract and service performance is $r=0.827, p<0.01$, and the three variables have significant positive correlation at the level of $\mathrm{P}<0.01$.

(2) There is a significant positive correlation among the three variables of job satisfaction, psychological contract and service performance. There is a positive relationship between job satisfaction and psychological contract of event volunteers. In other words, the higher the job satisfaction of event volunteers, the better their perception of psychological contract, which will easily induce pro-organizational behavior of volunteers. On the contrary, the lower the job satisfaction, the worse their perception of psychological contract of event volunteers, which will lead to anti-organizational behavior. The fulfillment of psychological contract has a significant positive effect on the service performance of event volunteers that the higher the fulfillment of psychological contract is, the better the service performance of event volunteers will be.

(3) Event volunteers' psychological contract plays a significant mediating role between job satisfaction and service performance. The higher the job satisfaction of event volunteers, the better their perception of psychological contract, the better their performance in competition service. Psychological contract acts as an mediating variable between job satisfaction and service performance of event volunteers. Event volunteers' job satisfaction affects employees' work enthusiasm and organizational identity through psychological contract perception. Good perception of psychological contract caused by the improvement of job satisfaction of event volunteers will stimulate volunteers to work more than expected, otherwise, it will lead to low enthusiasm of volunteers, low service quality, and even cause volunteers to quit halfway. Therefore, in order to improve the performance of volunteer service, the organizers should pay attention to not only improving the job satisfaction of volunteers, but also their psychological expectations, and give full play to the role of psychological contract as an mediating variable in the performance of volunteer service.

\subsection{Suggestions}

(1) A good communication channel between the event organizers and volunteers should be established so that the event organizers can understand in time and try their best to meet the reasonable psychological expectations of the event volunteers, improve their job satisfaction and psychological contract fulfillment, motivate their work enthusiasm and enhance their service performance.

(2) A scientific and reasonable incentive mechanism for event volunteers should be established. In view of the different participation motives of the event volunteers and the different psychological expectations of the organizers, different incentives should be adopted to enhance the pertinence of the incentives, which is more beneficial to improve the satisfaction of the event volunteers and the fulfillment of psychological contracts, and promote the improvement of the management level of the organizers.

\section{Acknowledgements}

This paper was financially supported by the National Social Science research Fund (16BTY012).

ISSN: 0010-8189 


\section{References}

[1] W. Liu, M.N. He, B. Yang, "Study on the relationship between job satisfaction, psychological contract and extra-role behavior based on mediating role of psychological contract," Statistics and Management, no. 04, pp. 46-48, 2013.

[2] G. Lei, "impact of charming leadership on employee performance: mediating role of psychological contract," Leadership Science, no. 10, pp. 47-50, 2020.

[3] H.B. Bai, "Relationship between job satisfaction and job performance of township civil servants in Beijing," Beijing: Minzu University of China, 2013.

[4] D.H. Sheng, "The relationship between attribution, job stress, job satisfaction and job performance of post-85 knowledge workers," Guangzhou: South China University of Technology, 2014.

[5] H. Zhang, "Relationship between employee communication satisfaction, job satisfaction and job performance," Yunnan: Yunnan University of Finance and Economics, 2014.

[6] X.J. Wang, "Relationship between job satisfaction, organizational commitment and job performance of employees in evaluation institutions," Zhejiang: Zhejiang University of Finance and Economics, 2016.

[7] Y. Wen, "Empirical study on the relationship between HR efficiency, job satisfaction and organizational performance," Anhui: Anhui University of Finance and Economics, 2016.

[8] J.R. Zhang, P. Shen, A.M. Zhu, H. Ling, "Relationship between work values, job satisfaction and work performance of community workers," Chinese Journal of Clinical Psychology, vol. 25, no. 01, pp. 178-181, 2017.

[9] T.Y. Hui, "Empirical study on the relationship between job satisfaction and performance of R\&D personnel," Science of Science and Management of S.\&.T., no. 05, pp. 145-148+156, 2006.

[10] X. Zhang, "Empirical study on the relationship between job satisfaction and performance of higher vocational teachers," Brand (Theoretical Monthly), no. 02, pp. 51-54, 2011.

[11] W.K. Ma, "The relationship between organizational support, job satisfaction and job performance of new generation knowledge workers," Shanghai: East China Jiaotong University, 2016.

[12] Y.Q. Xiong, Y.D. Qu, "Empirical study on the relationship between psychological contract and employee satisfaction," Technological Development of Enterprise, no. 01, pp. 73-75, 2007.

[13] Z.H. Wu, "Customer satisfaction and loyalty of third party logistics company based on psychological contract," China Business and Market, vol. 28, no. 05, pp. 101-105, 2014.

[14] M. Tan, H.Q. Fang, "Study on the relationship between psychological contract and job satisfaction of new generation female migrant workers," Modern Distance Education, no. 01, pp. 16-22, 2014.

[15] S.H. Bai, "The relationship between university teachers' psychological contract, job satisfaction and turnover tendency," The Party Building and Ideological Education in Schools, no. 20, pp. 68-70, 2014.

[16] Y.J. Jiang, "Relationship between psychological contract of community workers and intention to leave work with job satisfaction as the medium," Data of Culture and Education, no. 22, pp. 98-99+164, 2019.

[17] F. Jin, Y.M. Zhao, Z. Wang, "Relationship between fulfillment of psychological contract and job satisfaction of preschool teachers," Theory and Practice of Contemporary、Education, vol. 12, no. 02, pp. 143-148, 2020.

[18] L. Yuan, B. Dai, L.L. Zhang, "The impact of breaking psychological contract under the regulation of group identity on employee satisfaction," Soft Science, vol. 28, no. 08, pp. 56-59, 2014.

[19] Y.Y. Xu, "The relationship between psychological contract, job satisfaction and university teachers' burnout," Xinxiang: Henan Normal University, 2014.

[20] K. ROGALSKY, A. DOHERTY, K.F. PARADIS, "Understanding the sport event volunteer experience:an investigation of role ambiguity and its correlates," Journal of Sport Management, vol. 30, no. 4, 2016, in press.

[21] M.S. CHRISTIAN, A.S. GARZA, J.E. SLAUGHTER, "Work engagement:a quantitative review and test of its relations with task and contextual performance," Personnel Psychology, vol. 64, no. 1, pp. 89-136, 2011.

ISSN: 0010-8189

(C) CONVERTER 2021 
[22] J.B. ALLEN, M. BARTLE, “Sport event volunteers' engagement: management matters,” Managing Leisure, vol. 19, no. 1, pp. 36-50, 2014.

[23] D.D. Li, B. Meng, H.M. Huang, X.M. Yang, Y.L. Qi, "The impact of nurses' psychological contract on work performance in public hospitals," Journal of Bengbu Medical College, vol. 42, no. 01, pp. 13-17, 2017.

[24] D. Kou, "An Empirical Study on the impact of psychological contract on work performance of post-85 employees in state-owned enterprises," Shandong University of Science and Technology, 2018.

[25] Z.W. Yi, "The impact of psychological contract on police performance," Northwest Agriculture \& Forestry University, 2018.

[26] Q.Y. Qiao, "Empirical study on the impact of psychological contract violation on organizational commitment and job performance," Enterprise Reform and Management, no. 01, pp. 86-87, 2020.

[27] D.D. Li, Y.L. Qi, “The impact of psychological contract on work performance," Journal of Bengbu Medical College, vol. 40, no. 10, pp. 1454-1457, 2015.

[28] L. Ma, Y. Wang, Y. Xing, "Relationship between employee job satisfaction, organizational commitment and job performance," Enterprise Economy, vol. 32, no. 05, pp. 68-71, 2013.

[29] C. Li, L. Zhang, Y.J. Su, "Empirical study on the relationship between salary structure, job satisfaction and work performance of university teachers," Fudan Education Forum, vol. 14, no. 05, pp. 89-95, 2016.

[30] L.J. Lai, "Relationship between psychological contract, job satisfaction and turnover intention," China University of Geosciences (Beijing), 2016.

[31] G. Lei, "Impact of charming leadership on employee performance: mediating role of psychological contract," Leadership Science, no. 10, pp. 47-50, 2020.

[32] Y.J. Huang, L. Wang, L.L. Zhu, "Psychological contract and job performance based on a case study of a government department in J City of Shandong Province," Theoretical Exploration, no. 04, pp. 106-109, 2011.

[33] X.Y. Zhang, W. Li, G.L. Zhang, W.B. Cai, J. Zhuang, Y.J. Li, "Impact of doctor-patient relationship and job satisfaction on job performance of medical staff in a hospital in Yiliang County, Kunming," Medicine and Society, vol. 33, no. 03, pp. 92-95, 2020.

[34] "Impact of relationship psychological contract on hotel employee performance in China," Modern Business, no. 30, pp. 124-126, 2020.

[35] G. CUSKELLY, R. HOYE, C. AULD, "Working with volunteers in sport," Abingdon:Routledge, 2006.

[36] D. Zang, "Impact of break of psychological contract on work performance of knowledge workers in IT enterprises,” Dalian: Dalian Maritime University, 2019.

[37] S.Y. Zhong, "Impact of non-material motivation on knowledge workers' work performance," Changsha: Hunan Normal University, 2016. 